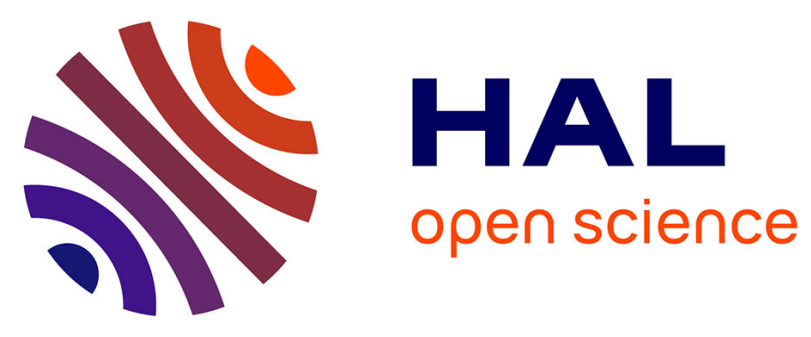

\title{
Tea brewed in traditional metallic teapots as a significant source of lead, nickel and other chemical elements
}

Fabien Bolle, Wendy Brian, Khalid Boutakhrit, Guillaume Feraille, Daniel Petit, Joris van Loco

\section{To cite this version:}

Fabien Bolle, Wendy Brian, Khalid Boutakhrit, Guillaume Feraille, Daniel Petit, et al.. Tea brewed in traditional metallic teapots as a significant source of lead, nickel and other chemical elements. Food additives and contaminants, 2011, pp.1. 10.1080/19440049.2011.580010 . hal-00717077

\section{HAL Id: hal-00717077 \\ https://hal.science/hal-00717077}

Submitted on 12 Jul 2012

HAL is a multi-disciplinary open access archive for the deposit and dissemination of scientific research documents, whether they are published or not. The documents may come from teaching and research institutions in France or abroad, or from public or private research centers.
L'archive ouverte pluridisciplinaire HAL, est destinée au dépôt et à la diffusion de documents scientifiques de niveau recherche, publiés ou non, émanant des établissements d'enseignement et de recherche français ou étrangers, des laboratoires publics ou privés. 


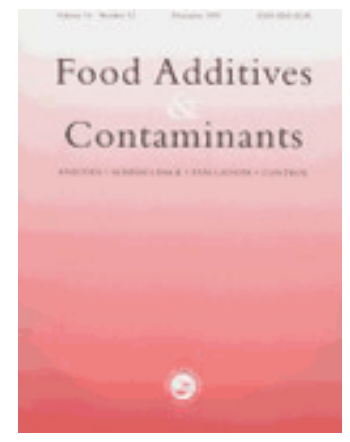

\section{Tea brewed in traditional metallic teapots as a significant source of lead, nickel and other chemical elements}

\begin{tabular}{|c|c|}
\hline Journal: & Food Additives and Contaminants \\
\hline Manuscript ID: & TFAC-2010-514.R1 \\
\hline Manuscript Type: & Original Research Paper \\
\hline $\begin{array}{r}\text { Date Submitted by the } \\
\text { Author: }\end{array}$ & 28-Mar-2011 \\
\hline Complete List of Authors: & $\begin{array}{l}\text { BOLLE, Fabien; Scientific Institute Of Public Health, Food } \\
\text { Brian, Wendy; Scientific Institute Of Public Health, Food } \\
\text { Petit, Daniel; Free University of Brussels, Department of Chemistry, } \\
\text { Faculty of Science } \\
\text { BOUTAKHRIT, Khalid; Scientific Institute Of Public Health, FOOD } \\
\text { Feraille, Guillaume; Scientific Institute Of Public Health, Food } \\
\text { Van Loco, Joris; Scientific Institute Of Public Health, FOOD }\end{array}$ \\
\hline Methods/Techniques: & Metals analysis - ICP \\
\hline Additives/Contaminants: & Food contact materials, Food simulants, Migration, Toxic elements \\
\hline Food Types: & Beverages \\
\hline Abstract: & $\begin{array}{l}\text { An environmental inquiry conducted by the Brussels Inter- } \\
\text { communal Laboratory of Chemistry and Bacteriology (BILCB) has } \\
\text { revealed that a traditional metallic teapot provoked in the year } \\
2000 \text { in Brussels a lead intoxication among a family of Morocco } \\
\text { origin. Following this case-study of lead poisoning and subsequent } \\
\text { preliminary results carried out by the BILCB, which confirmed the } \\
\text { dangerousness of this kind of item, samples of traditional metallic } \\
\text { teapots were collected from North African groceries in Brussels by } \\
\text { the Institute of Public Health (IPH) in collaboration with the BILCB } \\
\text { and the Federal Agency for the Safety of the Food Chain (FASFC). } \\
\mathrm{Al}, \mathrm{Cu}, \mathrm{Fe}, \mathrm{Ni} \text {, Pb and Zn were analysed to identify metals with a } \\
\text { potential to migrate in tea solutions. Simulants (nature tea, tea } \\
\text { acidified with citric acid and citric acid) were brewed in those } \\
\text { teapots in order to identify the leaching potential of migration at } \\
\text { boiling point temperature for different contact periods. Multi- }\end{array}$ \\
\hline
\end{tabular}


elementary analysis was carried out by ICP-AES. We concluded that the concentrations of those leached metals depend on the nature of the migration liquids, the type of teapots and the contact periods. Most of teapots showed a high level of toxic metals in leachates for lead and to a less extent for nickel which can contribute significantly to the risk of serious poisoning. A comparison of the results to the toxicological reference values was done. The teapots were withdrawn from the market by the FASFC.

\section{SCHOLARONE \\ Manuscripts}




\title{
Tea brewed in traditional metallic teapots as a significant source of lead, nickel and other chemical elements
}

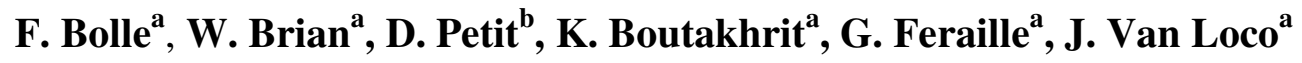

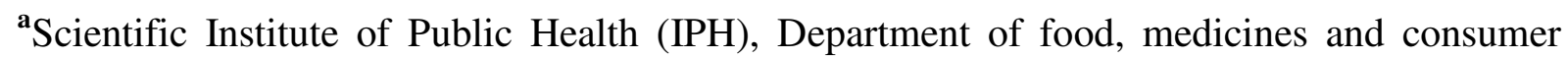 \\ safety, Juliette Wytsmanstreet 14, B-1050 Brussels, Belgium; \\ ${ }^{\mathbf{b}}$ Present address: Department of Chemistry, Faculty of Science, Free University of Brussels, \\ Pleinlaan, 2, B-1050 Brussels, Belgium.
}

Key words: teapot, food contact, migration, ICP-AES, exposure, metals

\begin{abstract}
An environmental inquiry conducted by the Brussels Inter-communal Laboratory of Chemistry and Bacteriology (BILCB) has revealed that in 2000 a traditional metallic teapot caused in Brussels lead intoxication among a family of Morocco origin.

Following this case-study of lead poisoning and subsequent preliminary results carried out by the BILCB, which confirmed the dangerousness of this kind of item, samples of traditional metallic teapots were collected from North African groceries in Brussels by the Institute of Public Health (IPH) in collaboration with the BILCB and the Federal Agency for the Safety of the Food Chain (FASFC). Al, Cu, Fe, Ni, Pb and Zn were analysed to identify metals with a potential to migrate in tea solutions. Simulants (nature tea, tea acidified with citric acid and citric acid) were brewed in those teapots in order to identify the leaching potential of migration at boiling point temperature for different contact periods. Multi-elementary analysis was carried out by ICP-AES. We concluded that the concentrations of those leached metals depend on the nature of the migration liquids, the type of teapots and the contact periods. Most of teapots showed a high level of toxic metals in leachates for lead and to a less extent for nickel which can contribute significantly to the risk of serious poisoning. A comparison of the results to the toxicological reference values was done. The teapots were withdrawn from the market by the FASFC.
\end{abstract}

\footnotetext{
* Corresponding author: Tel. \& Fax.: 003226425207 \& 003226425327

E-mail: Khalid.Boutakhrit@wiv-isp.be
} 


\section{MATERIALS AND METHODS}

\section{Sampling}

It is well-known that among the $\mathrm{Al}, \mathrm{Cu}, \mathrm{Fe}, \mathrm{Ni}, \mathrm{Pb}$ and $\mathrm{Zn}$ analysed in the present study, lead is the most toxic metal for the human body, particularly for children (Cleays et al., 2003). Since antiquity, lead poisoning occurred in utensils used in food contact (Milton et al., 1988). Nowadays, cases of poisoning by this route are considered as unusual (Wilson et al. 1986). With the exception of Petit et al., (2003) who reports a case-study of lead poisoning following the use of metallic teapots, most cases are identified for "mugs" (Ajmal et al., 1997; Ziegler et al., 1988 and Zuckerman et al., 1989), earthenware containers (Hellström et al., 2006) or ceramics (Hellström et al., 1997 and Phan et al., 1998).

To our knowledge, few studies were dedicated to the origin of migration process in metallic teapots. We have found in the literature only two studies, one which studied copper, Lixiao et al., (2008) and an older one which investigated Zinc, Nickel, Copper and Tin, Boularbah et al., (1999).

At the request of the BILCB (Brussels Inter-communal Laboratory of Chemistry and Bacteriology), the ISP made an environmental inquiry in Brussels, where a case of lead poisoning was reported (Petit et al., 2003) through use of a traditional metallic teapot.

A preliminary study made by the BILCB, has envisaged the leaching of lead brewed in those kind of metallic teapots: the concentrations of lead were on the order of a few hundred of $\mu \mathrm{g} / \mathrm{l}$ but could be in some cases much higher (up to about $3.5 \mathrm{mg} / \mathrm{l}$ ), which confirmed the potential danger of using those items (Petit et al., 2003).

These items were very commonly used in families coming from Magrebbian or Minor Asia countries. It is also possible to find these products in snacks, tearooms or oriental restaurants willing to bring a touch of traditional products they serve their customers.

To the extent that they contain substantial amounts of lead and other metals to the known toxicity, IPH has taken the initiative to investigate the levels of presence and confronted with the toxicological reference values. These results have led to market withdrawals made by the FASFC.

Despite the particularly dangerous nature of these products, the European Commission has not established and does not produce specific guidelines on the subject. Therefore, the Council of Europe has taken the initiative to initiate a resolution on metals and alloys. This could therefore provide a legal basis for consolidated operations of public authorities.

The objective of this investigation was to study the migration of toxic metals from metallic teapots by using different simulants and to assess the related risks by comparing the results to the established toxicological safety limits. 
Teapots samples (figure 1) were collected from two places in Brussels well-known for the sale of these products. Two shops were visited in each area and one sample of each model of teapots was bought (codes AS and RB). A total of 9 items have been purchased. It is sometimes difficult to determine the origin of these products, but these shops are specialized in products from North Africa. Samples code as "1RB1" were collected in three identical copies in order to make a comparison between migration tests.

Other series of 11 teapots was provided by the FASFC, those items, bought also in North African groceries were originated-from India and Morocco.

\section{Migration procedure}

Teapots were cleaned before contact with different leaching media, washed by using a detergent and rinsed with Milli-Q water, then dried at room temperature.

Three simulants were used as leaching medium: tea infusions (prepared by boiling 6 bags in 1 litre Milli-Q water; $\mathrm{pH} 4.86)$, citric acid $(99.5 \%(\mathrm{~m} / \mathrm{m})$, Merck) by dissolving $1 \mathrm{~g}$ in $1 \mathrm{~L}$ of Milli-Q water ( $\mathrm{pH} 2.7)$ and the mixture of tea nature and citric acid (1 g/L).

Teapots were filled with the leaching solution up to $1 \mathrm{~cm}$ from the top and placed on a hotplate for heating; aliquots of $2 \mathrm{~mL}$ were taken after a period of 15, 30, 45 and $60 \mathrm{~min}$. of contact. These aliquots were then diluted to $10 \mathrm{~mL}$. Before analysis, acidification or dilution with nitric acid $2 \%(\mathrm{v} / \mathrm{v})$ was performed.

The aim of the choice of citric acid was made in the context of worst case conditions. It is therefore that the leaching media were used in place of acetic acid that is generally chosen as standard for example in ceramic materials in contact with food (European Committee for Standardization, 1995). It was decided because it is more realistic to simulating the lemon action used in making some of our tea infusions. A comparison (for three identical pieces) from three migration solutions include: citric acid, $1 \mathrm{~g} / \mathrm{L}$ with $\mathrm{pH} 2.7$ similar to the commercial lyophilized tea ( $\mathrm{pH}$ of 2.95), tea and tea acidified with citric acid $1 \mathrm{~g} / \mathrm{L}$ was also performed.

The use of citric acid helps standardize acidity of the juice and corresponds to a current consumption pattern. This standardization would not be possible using a real lemon. Citric acid helps, moreover, to explore the possibility of using a standard simulant in the laboratory and within the logic "Worst case" that prevails in Europe, in establishing the compliance of a material or article intended for food contact (Regulation 1935/2004/EC). This simulant also avoids having to work with significant levels of blank in testing migration. The concentration of some elements in tea is likely distorting the evaluation results.

\section{Digestion procedures}

First, the teapots were drilled with a drilling machine. Approximately $0.05 \mathrm{~g}$ of metal powder was weighed in PFA digestion Tube, then, $3 \mathrm{~mL} \mathrm{HCl}+1 \mathrm{~mL} \mathrm{HNO}_{3}$ were added. Afterwards, digestion was carried out at $180^{\circ} \mathrm{C}$ in the oven and evaporated to about $0.5 \mathrm{~mL}$. Each digested sample was transferred quantitatively into a $50 \mathrm{~mL}$ calibrated tube and set to volume with Milli-Q water. 


\section{ICP-AES determination of metals}

A routine method for the determination of metals in migration liquid with inductively coupled plasma atomic emission spectrometry (ICP-AES) was validated and accredited for several elements. The LOD, defined as three times the standard deviation of the blank, were less than $10 \mu \mathrm{g} / \mathrm{L}$ for all elements analysed, the within-laboratory reproducibility was less than $5 \%$ and the expanded measurement uncertainty were less than $15 \%$ for all element measured. An external calibration curve was carried out with the following standards: 25, 50, 100 and 200 $\mu \mathrm{g} / \mathrm{L}$, all standards were prepared by weighing a solutions $(1 \mathrm{~g} / \mathrm{L}$, Fluka) in $2 \%(\mathrm{v} / \mathrm{v})$ nitric acid $(70 \%(w / w)$, J.T. Baker). The samples solutions were measured in triplicate (instrument programmed) with ICP-AES (Perkin-Elmer Optima 4300DV, Norwalk, CT, USA). Samples were diluted in nitric acid $2 \%(\mathrm{v} / \mathrm{v})$ and reanalyzed when concentration appeared to exceed the highest concentration of the calibration curve. An internal control during the samples analysis was performed; check of the slope values and the coefficient of the correlation, analyse of one standard each ten samples measurement.

The concentrations of heavy metals were determined in each leaching solution, regarded as procedural blank (the leaching medium were placed in a Pyrex baker), before the migration test. In the citric acid simulant, all metals content were less than the LOD of the method (10 $\mu \mathrm{g} / \mathrm{L}$ ). For the tea nature used as leaching solution, the predominant present metals were (in $\mathrm{mg} / \mathrm{L}): \mathrm{Al}(4.2 \pm 0.3), \mathrm{Zn}(1.4 \pm 0.2), \mathrm{Mn}(0.93 \pm 0.09)$, and $\mathrm{Cu}(0.050 \pm 0.003)$. These concentrations values must be subtracted from the migrated values in subsequent migration test with tea nature.

\section{RESULTS AND DISCUSSION}

\section{Major composition of the teapots}

The composition of teapots was studied by dissolving a quantity of the alloys using aqua regia. A multi-elementary analysis were carried out by ICP-AES, this revealed that all teapots are made up by Brass alloy, meanly $59 \% \mathrm{Cu}$ and $36 \% \mathrm{Zn}$ and a majority of teapots are from leaded brass types because lead is known for its excellent ductility. We notice also the presence of others metals such as $\mathrm{Fe}, \mathrm{Al}$ and $\mathrm{Ni}$ at low contents. $\mathrm{Al}$ and $\mathrm{Ni}$ are added for their corrosion resistance properties (Table 1). On the basis of these results, we suspect the migration of $\mathrm{Cu}$ and $\mathrm{Zn}$ followed by $\mathrm{Pb}$, then $\mathrm{Fe}, \mathrm{Al}$ and $\mathrm{Ni}$ in certain cases.

\section{Comparison between simulants}

Three identical teapots (codes 1RB1 a, b, c) were used for this comparison. Three simulants were used for migration test; tea nature, citric acid and a mixture of tea and citric acid for different contact periods (Table 2).

The effect of $\mathrm{pH}$ is an important factor in the conduct of a migration study. The addition of citric acid was chosen because it is the main acid that can be found in a "lemon tea" and the concentration corresponds to the concentration of citric acid that we should expect to gain by adding a slice of lemon to a cup of tea. In this study, we considered that one slice, corresponding to $3.3 \mathrm{~mL}$ of juice, is equivalent to approximately $1 / 10$ of lemon $(80 \mathrm{~g} / \mathrm{L}$ of citric acid) in a cup of $250 \mathrm{ml}$. 
Leaching solutions, maintained at constant temperature, were taken at different contact periods $(15,30,45$ and $60 \mathrm{~min}$.) in order to assess the migration kinetics with time.

The results listed in Table 2 concern only the prevalent leached metals as $\mathrm{Pb}, \mathrm{Ni}$ and $\mathrm{Zn}$ after a 30 min contact period with the leaching medium. We notice that lead migrate more easily in these liquids compared to the other elements and this migration is stronger in the presence of citric acid which confirms that $\mathrm{pH}$ has a crucial part. It is allowed to conclude that the citric acid alone can be used as simulant "worst case". Moreover, the obtained concentrations for the metals listed above are not lower than those obtained after contact with tea-citric acid except for zinc. Furthermore, overvaluation (case of Lead and Nickel) or underestimation (case of Zinc) does not lead to unrealistic estimates and does not exclude the results out of a range of $50 \%$.

It is already established that the use of these teapots "1RB1" leads to high concentrations of Lead, Nickel and Zinc, and this even after 15 minutes of contact. The use of lemon juice actually leads to a significant increase in migration levels: up more than 8 to 10 times in the case of Lead.

\section{The kinetics of migration}

Kinetic migration studies were carried out with teapots bodies, filled up by leaching media as tea infusion and citric acid, at boiling temperature for 15, 30, 45 and 60 min contact period. Only the results concerning the migration of two toxic metals $(\mathrm{Pb}$ and $\mathrm{Ni}$ ) have been illustrated in figure 2 and 3. For lead and nickel, we observe similar behaviour, for almost teapot, both in tea leaching solution and citric acid; the release rate is higher at the first migration period of approximately $15 \mathrm{~min}$ and less than $50 \%$ of metals have been leached, after the rate of release decreases significantly with time. This can be explained partly by a gradual metals enrichment of the passive surface oxide layer, except for example teapots $n^{\circ} 6$ in case of $\mathrm{Ni}$ and $\mathrm{n}^{\circ} 11$ in case of $\mathrm{Pb}$ where the migration increased with time. Comparing the simulants, it appears that high concentration of metals have been released with citric acid which can be explained by $\mathrm{pH}$ difference.

\section{Metals analysis}

Table 3 displays the $\mathrm{Al}, \mathrm{Cu}, \mathrm{Fe}, \mathrm{Pb}, \mathrm{Ni}$ and $\mathrm{Zn}$ concentrations found in teapot leachates obtained by using citric acid as simulant for a contact period of $30 \mathrm{~min}$. Others elements as $\mathrm{Ag}, \mathrm{As}, \mathrm{B}, \mathrm{Ba}, \mathrm{Be}, \mathrm{Bi}, \mathrm{Cd}, \mathrm{Co}, \mathrm{Cr}, \mathrm{Mn}, \mathrm{Mo}, \mathrm{Sb}, \mathrm{Se}, \mathrm{Sr}$, and $\mathrm{V}$ were also analysed but they did not show any real interest at this stage of the study due to their negligible migration or to their absence in teapots composition and to their high level in tea infusion. The suggestion made before about the metals at high content (high migration of $\mathrm{Cu}$ and $\mathrm{Zn}$ ) likely to migrate from teapots is not confirmed except for the following teapots $n^{\circ} 2, n^{\circ} 11$ for copper and $n^{\circ} 2 R B 2$, $\mathrm{n}^{\circ} 8$ and $\mathrm{n}^{\circ} 10$ for zinc. All of the teapot leachates examined contained high concentrations of $\mathrm{Pb}$ and $\mathrm{Ni}$ then $\mathrm{Zn}$ or $\mathrm{Fe}$ and $\mathrm{Cu}$, the presence of other elements as $\mathrm{Al}$ depends on the type of teapot and its highest leached concentrations was found for teapot reference 2RB2. Teapot (1RB1a) released the highest concentration of lead and teapot (1AS1) for the nickel in spite of their low content in these teapots. From these results, we noticed that migration of metals did not match well with the content of these metals in teapot except for the cases quoted above. The migration phenomena of metals depends on electrochemical properties of elements, in spite of their low redox potentials $(\mathrm{Al} ;-1.66 \mathrm{~V}, \mathrm{Zn} ;-0.762 \mathrm{~V}, \mathrm{Fe} ;-0.44 \mathrm{~V})$, the corrosion of these elements is less than that of $\mathrm{Pb}$ and $\mathrm{Ni}$. These can be explained by the formation of a 
passivation layers or to the own structure of the brass, indeed, the alloy $\mathrm{Cu}-\mathrm{Zn}$ present a high corrosion resistance and only the added elements as $\mathrm{Pb}$ and $\mathrm{Ni}$ are very affected by the corrosion due perhaps to their non dissolution in the brass matrix.

\section{Comparison of the results to the toxicological reference values}

The objective is to confront the obtained values to the toxicological reference values (TRV expressed in mg/day: $\mathrm{Cu}: 5$; Fe: 17; Pb: 0.214; Ni: 0.7; Zn: 25)

These values are those currently adopted by the Council of Europe to draft a resolution in metallic materials and alloys in contact with food which consider a person of $60 \mathrm{~kg}$ weight (Draft resolution on metals and alloys 2010: 2, is not publicly available). The assumption would be a consumption of 4 cups, with a volume of $200 \mathrm{~mL}$ each one, of tea or nature tea with lemon (citric acid simulant), namely $800 \mathrm{~mL}$ per day. Here, it only takes a contact of 15 min.

For Copper, the comparison of the ingestion of copper compared to the toxicological reference value reveal that no surplus compared to TRV. But in the case of lemon tea, 4 of 11 teapots induce a surplus of up to $468 \%$.

For Iron, both in the case of tea nature or lemon tea, there are no surplus compared to TRV.

In case of Lead (Table 4), the comparison of the ingested lead, from nature tea, to the toxicological reference value shows a surplus in 8 cases per 11 teapots, and some of them go up to 6.5 times of the TRV. In the case of lemon tea ingestion, we exceeded the TRV with the 11 teapots and up to 90 times.

For Nickel, the comparison of ingested nickel to the toxicological reference values in the case of nature tea shows an excess in 8 cases per 11 teapots, and some of them go up to 4 times the TRV. In case of lemon tea, the ingested nickel exceeded the TRV in 10 per 11 teapots with and goes up to 15 times TRV.

In the case of Zinc, both for nature tea or lemon tea there are no surplus in all teapots.

\section{CONCLUSIONS}

It should be noted the potential risk of lead and nickel poisoning induce for the general population by some traditional metallic teapots which were currently found on the Belgian market. Consequently, exceed of the toxicological reference values (TRV) for lead and the nickel are very worrying and the asked assumptions are meant but not out. Factors such as a longer stay (migration up to 9 times higher after 1 hour rather than $15 \mathrm{~min}$.) could exacerbate the exposure. Use lemon is also aggravating since migration levels may be more than 10 times larger than with a nature tea. Also note in the case of lead, the sustained attention to have for populations most at risk as children (including cases cited above) since these, given the greater assimilation, are more susceptible than adults to lead poisoning. The other metals $(\mathrm{Al}, \mathrm{Cu}, \mathrm{Fe}$ and $\mathrm{Zn}$ ) envisaged in this study were not so problematic, they all fallen clearly below the TRV.

\section{Acknowledgments}


This work has benefited from the help of Dr. Petit from Inter-communal Laboratory of Chemistry and Bacteriology (BILCB) and the help of the Provincial unit of Control (UPC) in Brussels from the Federal Agency for the Safety of the Food Chain (FASFC) who by their kind collaboration allowed the culmination of this work.

\section{REFERENCES}

Ajmal M, Khan A, Nomani AA, Ahmed S. 1997. Heavy metals: leaching from glazed surfaces of tea mugs. Sci Total Environ. 207: 49-54.

Boularbah A., Bitton G, Morel JL. 1999. Assessment of metal content and toxicity of leachates from teapots. The science of the total Environment 227: 69-72.

Cleays F, Sykes C, Limbos C, Ducoffre G. 2003. Childhood lead poisoning in Brussels prevalence study and etiological factors. J. Phys. IV France 07:1-4.

Draft Resolution of council of Europe on Metals and alloys in contact with food. 2010, not published yet in the official journal.

European Committee for Standardization. EN 1388-1: Material and articles in contact with foodstuffs - Silicate surfaces - Part 1: Determination of the release of lead and cadmium from ceramic ware. Brussels 1995.

Hellstrom-Lindberg E, Bjorklund A, Karlson-Stiber C, Harper P. 1997. Extraction of lead, cadmium and zinc from overglaze decorations on ceramic dinnerware by acidic and basic food substances. Science of the total environment 197: 167-175.

Hellström-Lindberg E, Bjorklund A, Karlson-Stiber C, Harper P, Seldén AI. 2006. Lead poisoning from souvenir earthenware. Int Arch Occup Environ Health. 79:165-168.

Lixiao Ni, Shiyin Li. 2008. Effects of organic matters coming from Chinese tea on soluble copper release from copper teapot. Science of the total environment 389: 202-207.

Milton A., Lessler. 1965. Lead and Lead Poisoning from Antiquity to Modern Times. J. Sci. 88: 78-88.

Official Journal of the European Union. Regulation (EC) No 1935/2004 on materials and articles intended to come in to contact with food and repealing Directives 80/590/EEC and 89/109/EEC. L338/4. European Parliament and the Council, Strasbourg, France 2004.

Pedersen GA, Mortensen GK, Larsen EH. 1994. Beverages as a source of trace element intake. Food Add Contam. 11:351-363.

Petit D, Claeys F, Sykes C, Noefnet Y. 2003. Lead poisoning from metallic teapots traditionally used by North African populations, J Phys IV France 107: 1053-1056.

Phan TG, Estell J, Duggin G, Beer I, Smith D, Ferson MJ. 1998. Lead poisoning from drinking Kombucha tea brewed in a ceramic pot. Med J Aust 169:644-646. 
Wilson TW, Card RT. 1986. Lead poisoning: unusual manifestation and unusual source. CMAJ 135:773-775.

Ziegler S, Wolf C, Salzer-Muhar U, Schaffer A, Konnaris C, Rudiger H, Osterode W. 2002. Acute lead intoxication from a mug with a ceramic inner surface. Am J Med. 112:677-6784.

Zuckerman MA, Savory D, Rayman G. 1989. Lead encephalopathy from an imported Toby mug. Postgrad Med J 65:307-309.

Fig. 1 : Teapots samples collected from the market in Brussels

Fig. 2a : The evolution of lead migration, from various teapots, in nature tea migration liquid with the contact time.

Fig. $\mathbf{2 b}$ : The evolution of lead migration, from various teapots, in citric acid simulant with the contact period.

Fig. 3a : The evolution of Nickel migration, from various teapots, in nature tea migration liquid with the contact time.

Fig. 3b : The evolution of Nickel migration, from various teapots, in citric acid simulant with the contact period. 
Table 1 : Major composition of the teapots,

Table $2: \mathrm{Pb}, \mathrm{Ni}$ and $\mathrm{Zn}$ concentrations in various migration liquids from teapot for a contact time of $30 \mathrm{~min}$ at boiling temperature.

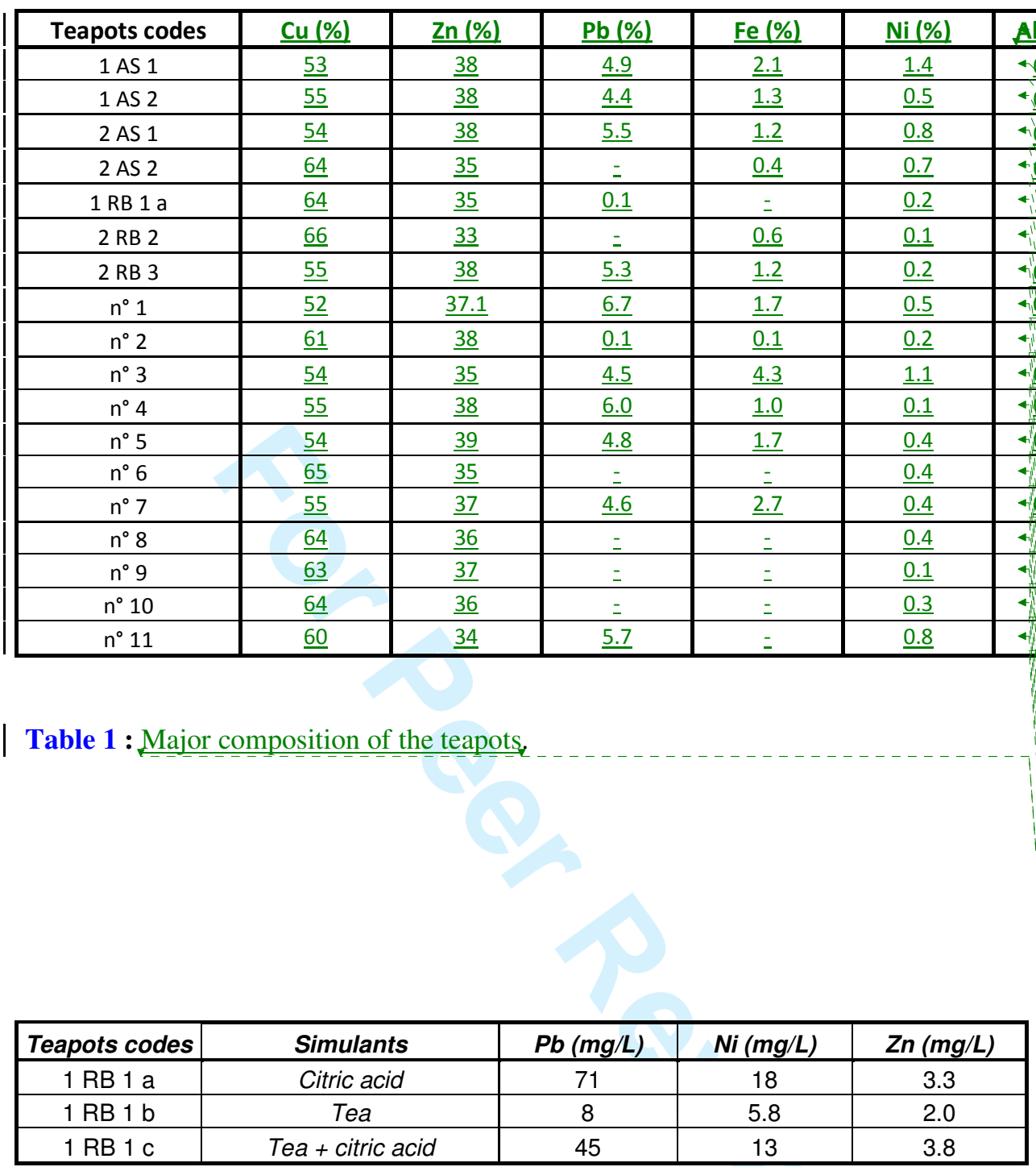

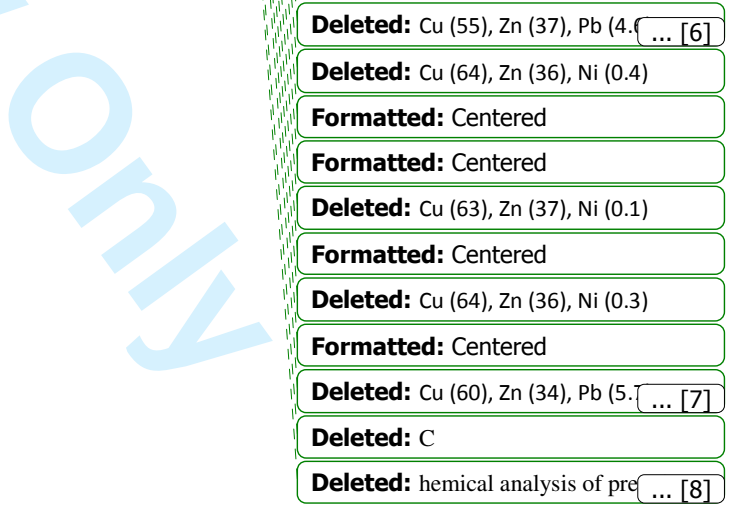




\begin{tabular}{|c|c|c|c|c|c|c|}
\hline Teapots codes & $\mathbf{A l}$ & $\mathbf{C u}$ & $\mathbf{F e}$ & $\mathbf{P b}$ & $\mathbf{N i}$ & $\mathbf{Z n}$ \\
\hline $\mathbf{1} \mathbf{A S} \mathbf{1}$ & 0.23 & 0.36 & 2.3 & 34 & 35 & 7.7 \\
\hline $\mathbf{1} \mathbf{A S} \mathbf{2}$ & 0.43 & 0.36 & 2.2 & 42 & 10 & 8.6 \\
\hline $\mathbf{2} \mathbf{A S} \mathbf{1}$ & - & - & 0.74 & 18 & 10 & 0.9 \\
\hline $\mathbf{2} \mathbf{A S} \mathbf{2}$ & - & - & 0.54 & 62 & 15 & 3.5 \\
\hline $\mathbf{1 ~ R B ~ 1 ~ a ~}$ & - & - & 0.6 & 71 & 18 & 3.3 \\
\hline $\mathbf{2} \mathbf{~ R B ~ 2}$ & 3.5 & 11 & 4.7 & 11 & 5.8 & 40 \\
\hline $\mathbf{2} \mathbf{R B} 3$ & 0.33 & - & - & 42 & - & - \\
\hline $\mathbf{n}^{\circ} \mathbf{1}$ & 0.31 & 0.15 & 3.82 & 36.5 & 10.6 & 2.2 \\
\hline $\mathbf{n}^{\circ} \mathbf{2}$ & 0.19 & 17.1 & 0.52 & 14.1 & 4.1 & 14.9 \\
\hline $\mathbf{n}^{\circ} \mathbf{3}$ & 0.16 & 13.9 & 2.01 & 16.7 & 1.2 & 8.1 \\
\hline $\mathbf{n}^{\circ} \mathbf{4}$ & 0.07 & 2.2 & 1.05 & 18.2 & 8.7 & 1.7 \\
\hline $\mathbf{n}^{\circ} \mathbf{5}$ & 0.19 & 0.33 & 4.35 & 28.7 & 9.9 & 2.1 \\
\hline $\mathbf{n}^{\circ} \mathbf{6}$ & 0.10 & 1.1 & 0.31 & 2.0 & 16.6 & 1.5 \\
\hline $\mathbf{n}^{\circ} \mathbf{7}$ & 0.31 & 0.41 & 3.3 & 23.7 & 10.7 & 3.7 \\
\hline $\mathbf{n}^{\circ} \mathbf{8}$ & 0.52 & 8.05 & 0.4 & 2.0 & 13.6 & 30.0 \\
\hline $\mathbf{n}^{\circ} \mathbf{9}$ & 0.37 & 1.85 & 0.13 & 1.3 & 15.6 & 9.6 \\
\hline $\mathbf{n}^{\circ} \mathbf{1 0}$ & 0.35 & 18.0 & 0.2 & 1.1 & 9.9 & 19.8 \\
\hline $\mathbf{n}^{\circ} \mathbf{1 1}$ & 1.1 & 40.8 & 0.62 & 36.2 & 18.6 & 24.1 \\
\hline
\end{tabular}

Table 3 : Metals concentrations $(\mathrm{mg} / \mathrm{L}$ ) in leachates of citric acid from various teapots after a contact period of $30 \mathrm{~min}$. 


\begin{tabular}{|c|c|c|c|c|}
\hline \multicolumn{5}{|c|}{ Lead (hypothesis of 4 tea cups/day [800 mL]) } \\
\hline Teapots $n^{\circ}$ & Migration liquid & $m g / L$ & $\mathrm{mg} / \mathrm{day}$ & $\% \mathrm{TRV}^{*}$ \\
\hline $\mathrm{n}^{\circ} 1$ & Nature tea & 1,74 & 1,4 & 650 \\
\hline$n^{\circ} 2$ & Nature tea & 0,84 & 0,7 & 314 \\
\hline$n^{\circ} 3$ & Nature tea & 0,71 & 0,6 & 264 \\
\hline$n^{\circ} 4$ & Nature tea & 0,18 & 0,1 & 66 \\
\hline $\mathrm{n}^{\circ} 5$ & Nature tea & 1,19 & 1,0 & 444 \\
\hline$n^{\circ} 6$ & Nature tea & 0,10 & 0,1 & 36 \\
\hline $\mathrm{n}^{\circ} 7$ & Nature tea & 1,49 & 1,2 & 557 \\
\hline $\mathrm{n}^{\circ} 8$ & Nature tea & 0,32 & 0,3 & 118 \\
\hline$n^{\circ} 9$ & Nature tea & 0,20 & 0,2 & 73 \\
\hline $\mathrm{n}^{\circ} 10$ & Nature tea & 0,34 & 0,3 & 129 \\
\hline $\mathrm{n}^{\circ} 11$ & Nature tea & 4,90 & 3,9 & 1830 \\
\hline $\mathrm{n}^{\circ} 1$ & Citric acid & 23,97 & 19,2 & 8961 \\
\hline$n^{\circ} 2$ & Citric acid & 9,10 & 7,3 & 3400 \\
\hline$n^{\circ} 3$ & Citric acid & 8,30 & 6,6 & 3101 \\
\hline $\mathrm{n}^{\circ} 4$ & Citric acid & 10,21 & 8,2 & 3816 \\
\hline$n^{\circ} 5$ & Citric acid & 13,12 & 10,5 & 4905 \\
\hline$n^{\circ} 6$ & Citric acid & 1,07 & 0,9 & 399 \\
\hline$n^{\circ} 7$ & Citric acid & 16,12 & 12,9 & 6027 \\
\hline $\mathrm{n}^{\circ} 8$ & Citric acid & 0,38 & 0,3 & 142 \\
\hline $\mathrm{n}^{\circ} 9$ & Citric acid & 0,42 & 0,3 & 157 \\
\hline $\mathrm{n}^{\circ} 10$ & Citric acid & 0,65 & 0,5 & 243 \\
\hline $\mathrm{n}^{\circ} 11$ & Citric acid & 17,60 & 14,1 & 6578 \\
\hline
\end{tabular}

| : Toxicological reference values

Table 4 : Comparison of the ingested lead, from nature tea and citric acid after a contact period of $15 \mathrm{~min}$, to the toxicological reference values. 
Page 1: [8] Deleted

KBoutakhrit 3/22/2011 10:46:00 AM $\mathrm{Cu}$ (52), Zn (37.1), Pb (6.7), Fe (1.7), Ni (0.5), Al (0.4)

\begin{tabular}{|c|c|c|}
\hline Page 1: [2] Deleted & $\begin{array}{l}\text { KBoutakhrit } \\
\end{array}$ & $3 / 22 / 2011$ 10:46:00 AM \\
\hline \multicolumn{3}{|c|}{$\mathrm{Cu}(61), \mathrm{Zn}(38), \mathrm{Ni}(0.2), \mathrm{Pb}(0.1), \mathrm{Fe}(0.1)$} \\
\hline Page 1: [3] Deleted & KBoutakhrit & \multirow[t]{2}{*}{ 3/22/2011 10:46:00 AM } \\
\hline \multicolumn{2}{|r|}{$\mathrm{b}(4.5), \mathrm{Fe}(4.3)}$, & \\
\hline Page 1: [4] Deleted & KBoutakhrit & $3 / 22 / 2011$ 10:46:00 AM \\
\hline \multicolumn{3}{|c|}{$\mathrm{Cu}(55), \mathrm{Zn}(38), \mathrm{Pb}(6.0), \mathrm{Fe}(1.0), \mathrm{Al}(0.2) \mathrm{Ni}(0.1)$} \\
\hline Page 1: [5] Deleted & KBoutakhrit & 3/22/2011 10:46:00 AM \\
\hline 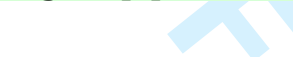 & \multicolumn{2}{|l|}{$\mathrm{Cu}(54), \mathrm{Zn}(39), \mathrm{Pb}(4.8), \mathrm{Fe}(1.7), \mathrm{Ni}(0.4), \mathrm{Al}(0.3)$} \\
\hline \multirow[t]{2}{*}{ Page 1: [6] Deleted } & KBoutakhrit & 3/22/2011 10:46:00 AM \\
\hline & \multicolumn{2}{|l|}{$\mathrm{Cu}(55), \mathrm{Zn}(37), \mathrm{Pb}(4.6), \mathrm{Fe}(2.7), \mathrm{Ni}(0.4), \mathrm{Al}(0.3)$} \\
\hline Page 1: [7] Deleted & KBoutakhrit & 3/22/2011 10:46:00 AM \\
\hline & $\mathrm{Cu}(60), \mathrm{Zn}(34), \mathrm{Pb}(5.7), \mathrm{Ni}(0.8)$ & \\
\hline
\end{tabular}

hemical analysis of prevalent heavy metals content in teapots components 


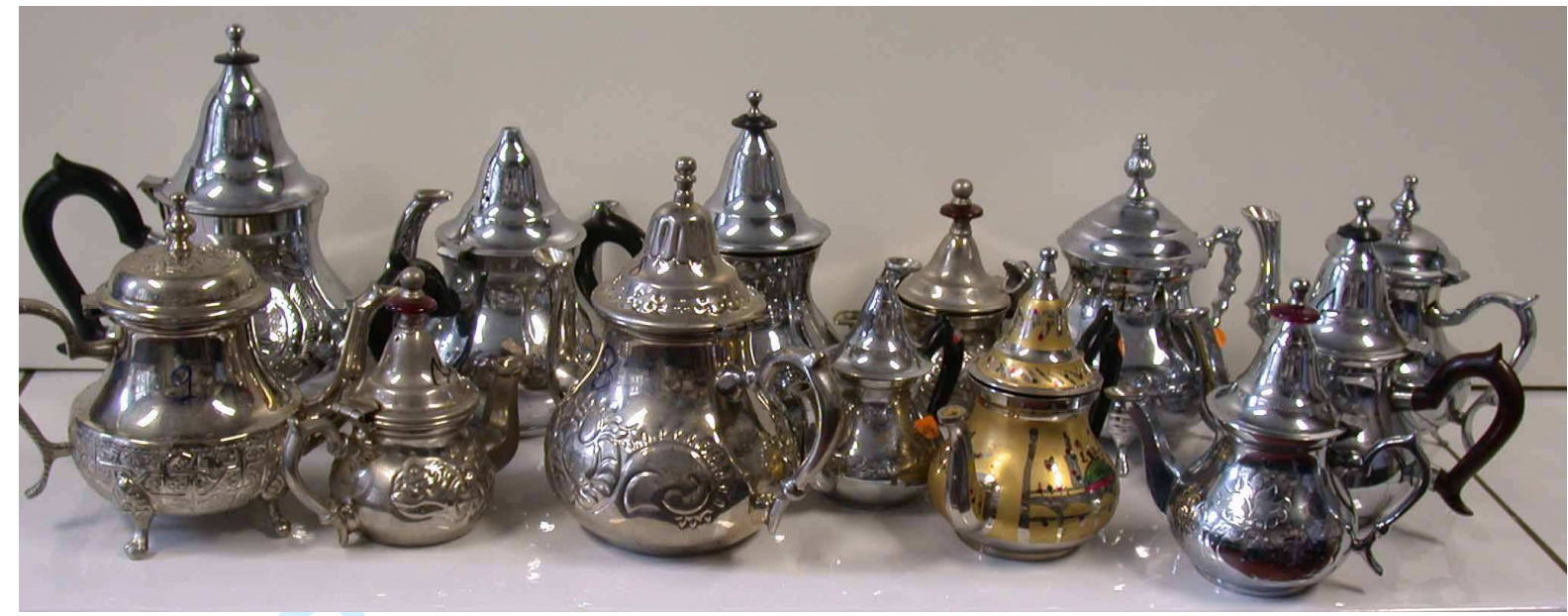

Fig. 1 


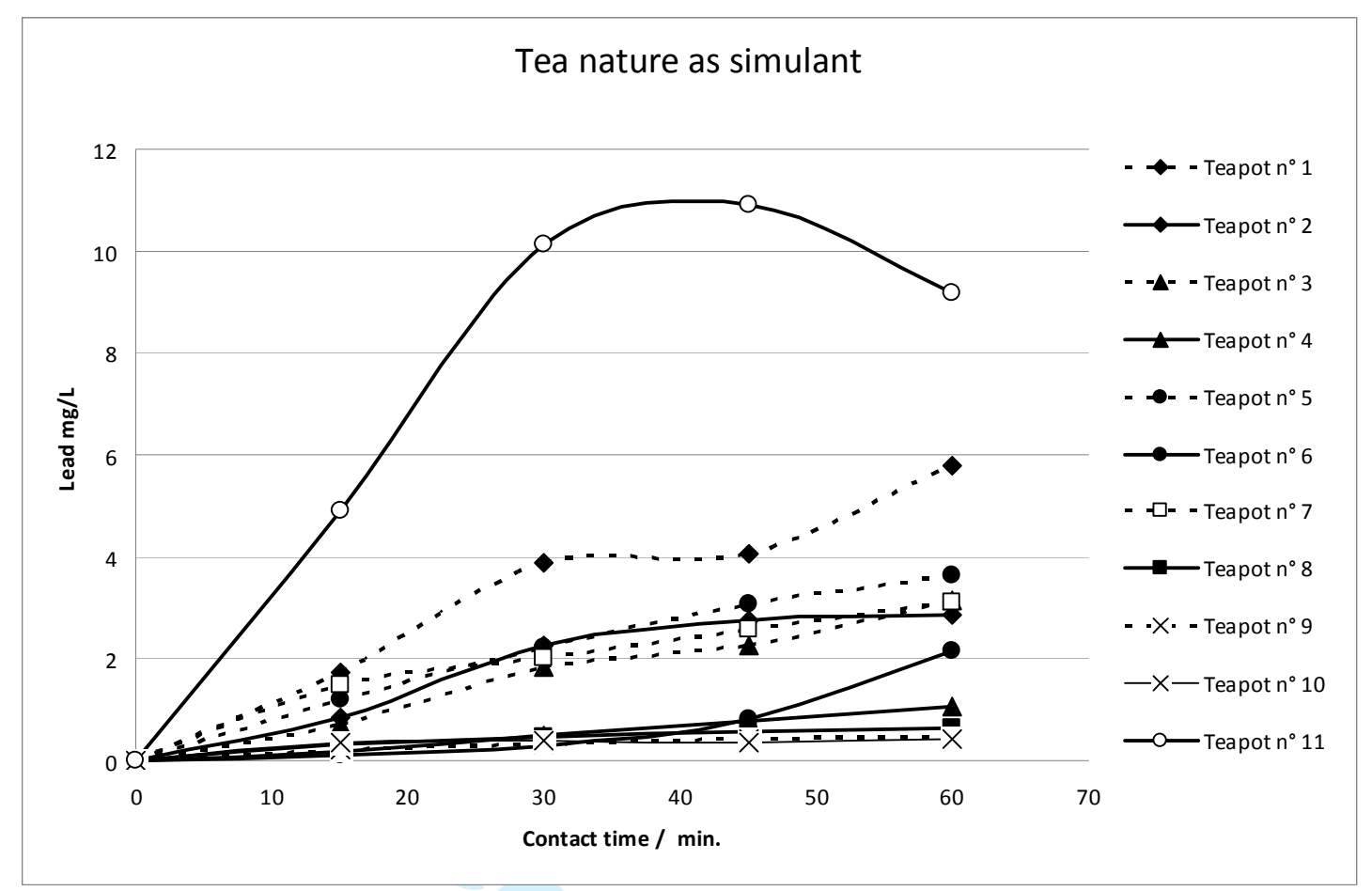

Fig. 2a

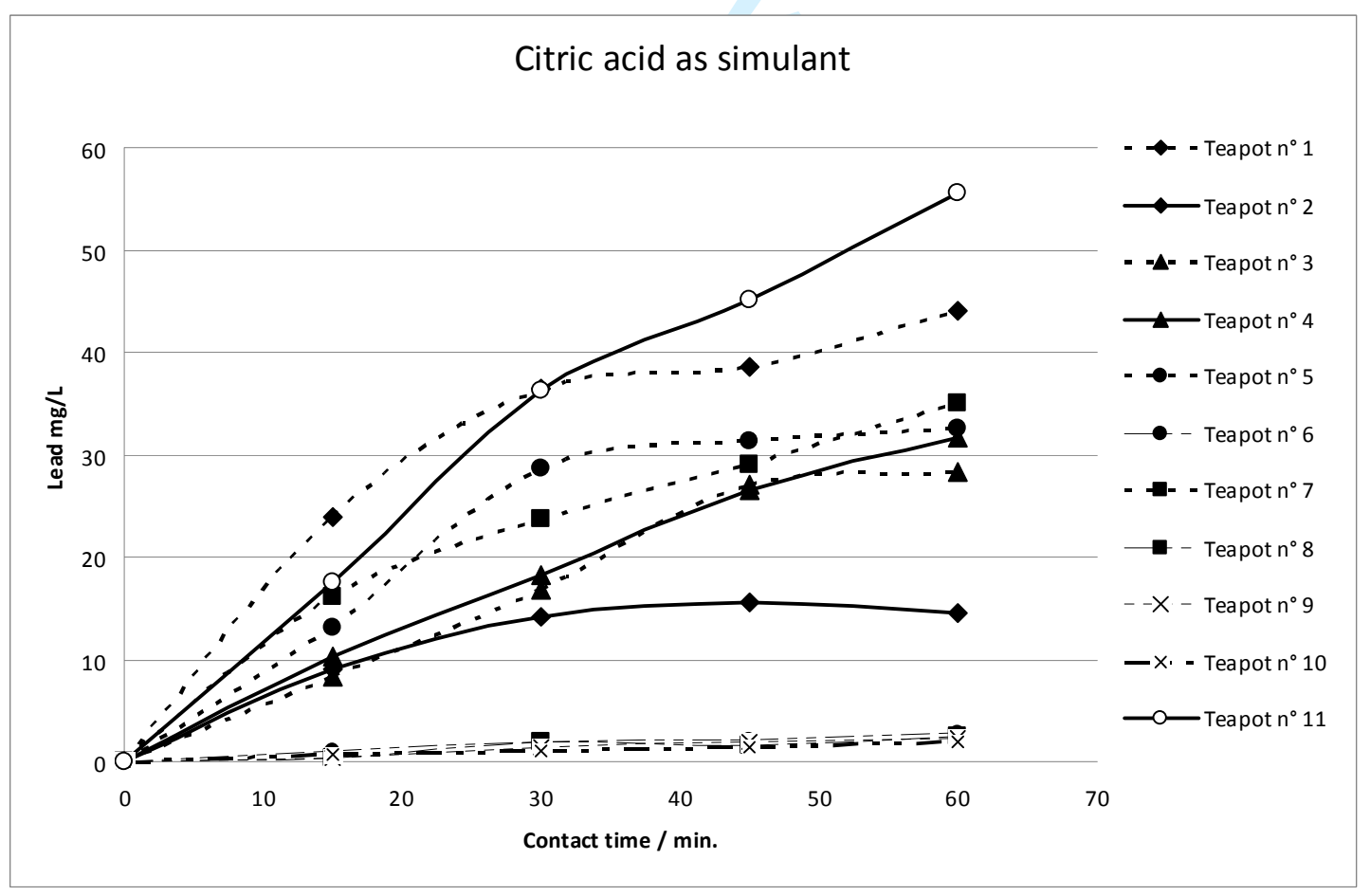

Fig. 2b 


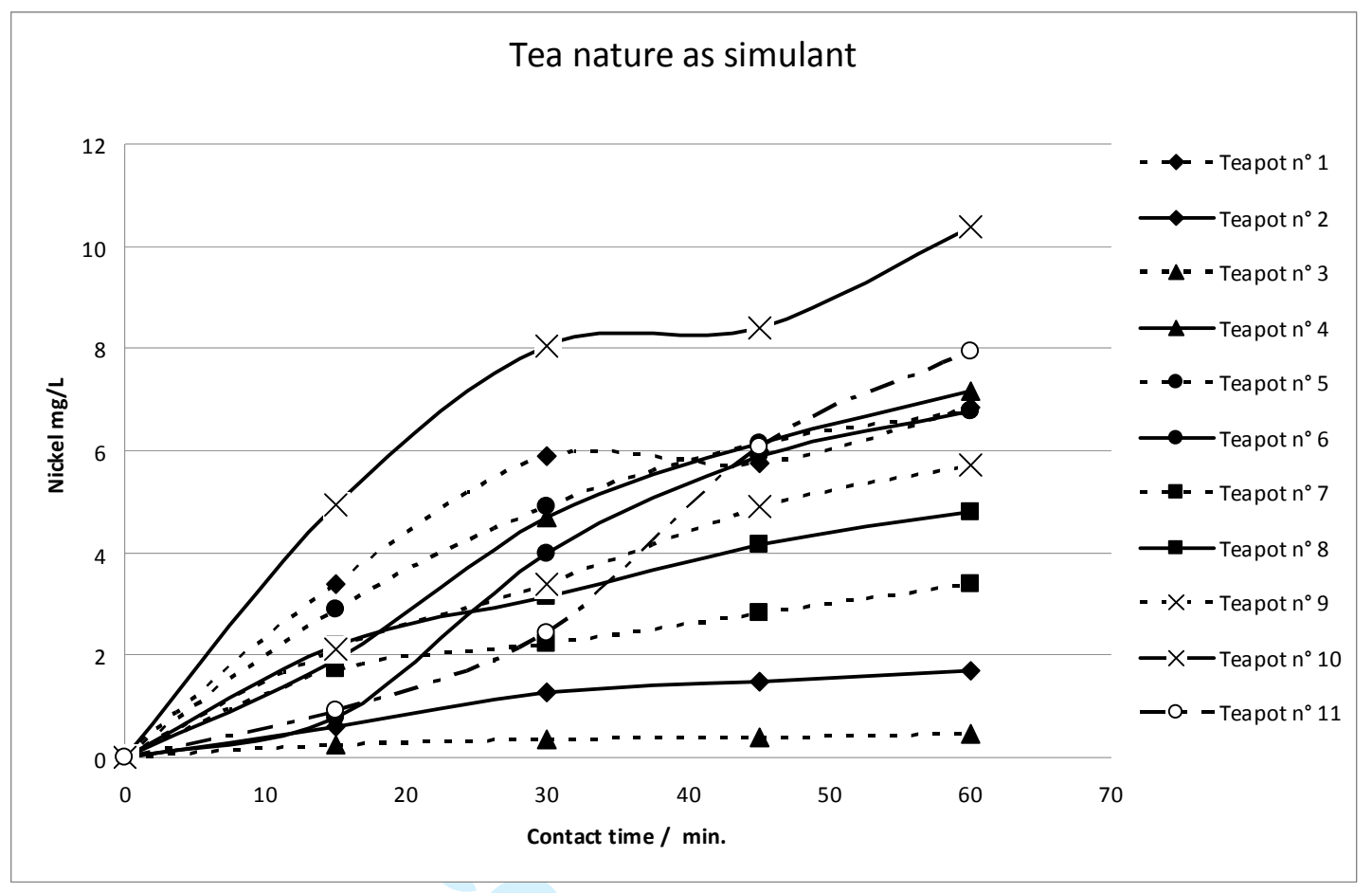

Fig. 3a

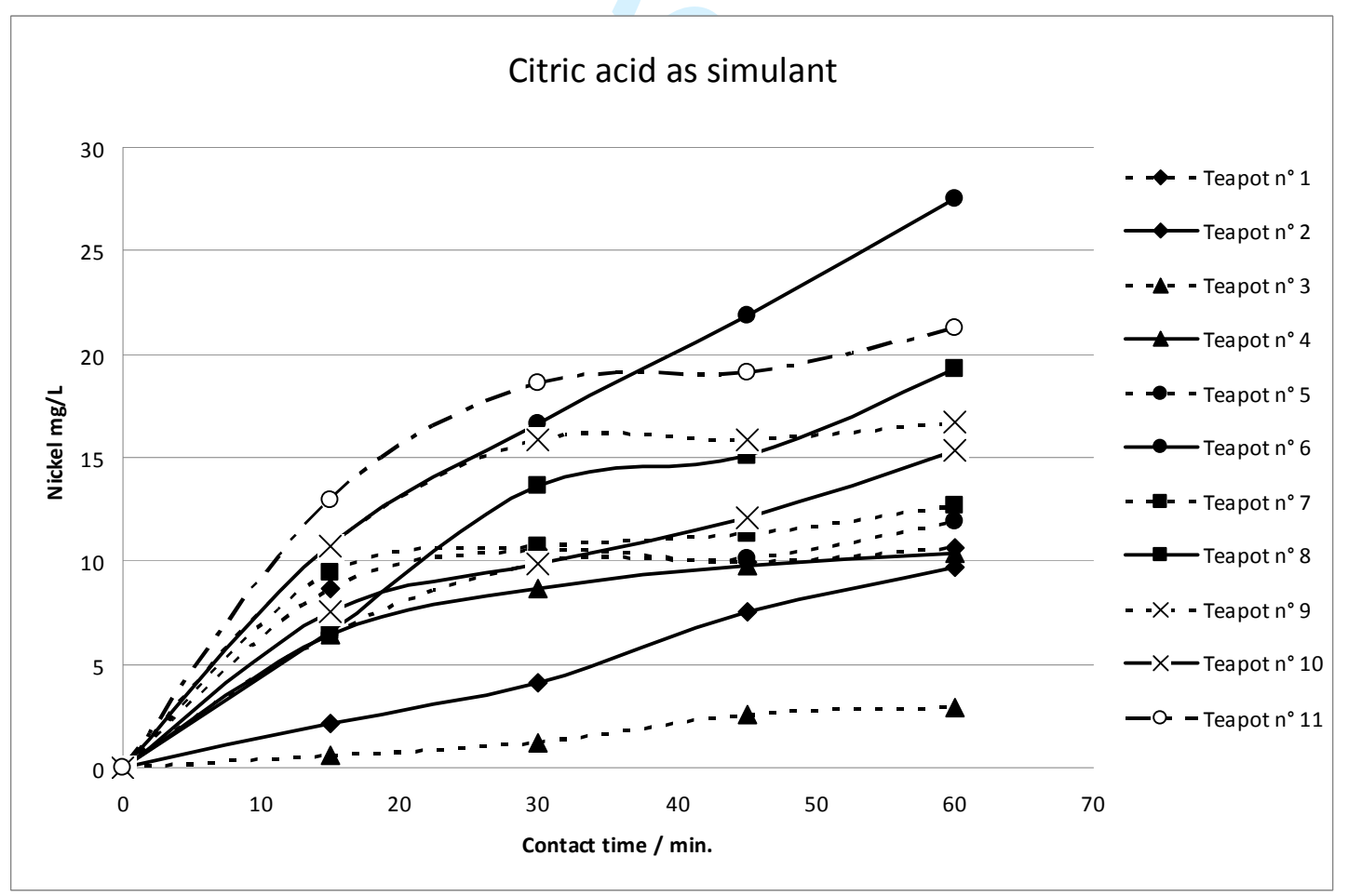

Fig. 3b 